\title{
Pharmacovigilance in juvenile idiopathic arthritis patients (Pharmachild) treated with biologic agents and/or methotrexate. Consolidated baseline characteristics from Pharmachild and other national registries
}

\author{
Joost Swart ${ }^{*}$, Alessandro Consolaro², Gerd Horneff ${ }^{3}$, BIKER, Kimme L Hyrich ${ }^{4}$, \\ UK BCRD Study Group and BSPAR Etanercept Study Group, Francesca Bovis ${ }^{2}$, Jose Melo-Gomes², \\ Ekaterina Alexeeva ${ }^{2}$, Stefano Lanni ${ }^{2}$, Gerd Ganser ${ }^{5}$, Violeta Panaviene ${ }^{2}$, Jordi Anton ${ }^{2}$, Ivan Foeldvari ${ }^{6}$, \\ Valda Stanevicha ${ }^{2}$, Susan Nielsen ${ }^{2}$, Ralf Trauzeddel ${ }^{7}$, Constantin Ailioaie ${ }^{2}$, Pierre Quartier ${ }^{2}$, Toni Hospach ${ }^{8}$, \\ Gordana Susic ${ }^{2}$, Maria Trachana ${ }^{2}$, Frank Weller-Heinemann ${ }^{9}$, Alberto Martini ${ }^{2}$, Nico Wulffraat ${ }^{2}$, Nicolino Ruperto ${ }^{2}$
}

From 21st European Pediatric Rheumatology (PReS) Congress

Belgrade, Serbia. 17-21 September 2014

\section{Introduction}

The availability of methotrexate (MTX) and biological agents has provided a major change in the treatment of children with juvenile idiopathic arthritis (JIA). An international registry named Pharmachild (European Union grant 260353) has been set up by the Pediatric Rheumatology International Trials Organisation (PRINTO)/Pediatric Rheumatology European Society (PRES). In parallel several national registries with the same purpose have been set up in different European Countries for the follow-up of these patients.

\section{Objectives}

To evaluate the possibility to combine data coming from different national registries in order to assess the long-term safety.

\section{Methods}

We merged into a unified database the baseline demographic data of JIA patients treated with MTX or biolo- gicals coming from the Pharmachild registry and from the national registries of Germany, United Kindgom and Portugal. Data are presented as frequencies (\%) or medians with 1st and 3rd quartiles.

\section{Results}

About $63 \%$ of the patients has been treated with biologicals alone or in combination with MTX, and $29 \%$ only with MTX. The events of special interest (ESI) ranged from 4.5 to $15.0 \%$ and the other moderate/severe/serious adverse events (AE) from $13.1 \%$ to $69.9 \%$. Table 1.

\section{Conclusion}

Combination of information from different data sources is a recommended task and will provide a powerful tool for the future analysis of safety events coming from different registries.

\section{Disclosure of interest}

None declared.

${ }^{1}$ UMC Utrecht, Utrecht, Netherlands

Full list of author information is available at the end of the article 
Table 1

\begin{tabular}{|c|c|c|c|c|c|}
\hline & $\begin{array}{l}\text { Pharmachild } \\
(\mathrm{N}=5571)\end{array}$ & $\begin{array}{c}\text { NR UK } \\
(\mathrm{N}=1537)\end{array}$ & $\begin{array}{l}\text { NR Germany } \\
(\mathrm{N}=3243)\end{array}$ & $\begin{array}{l}\text { NR Portugal } \\
(\mathrm{N}=112)\end{array}$ & $\begin{array}{c}\text { TOTAL } \\
(\mathrm{N}=10463) \\
\end{array}$ \\
\hline Age at onset & $5.4(2.4-10.0)$ & - & $7.2(3.1-11.4)$ & $6.3(2.5-10.9)$ & - \\
\hline Age at JIA Diagnosis & $6.2(2.8-11.0)$ & $5.5(2.1-10.2)$ & $8.2(4.0-12.3)$ & $7.3(3.3-12.3)$ & - \\
\hline Disease duration at the last follow-up & $4.9(2.5-8.2)$ & $5.4(2.7-8.8)$ & $5.2(3.1-8.4)$ & $3.0(0.5-9.6)$ & - \\
\hline Therapy with MTX only & $1365(24.5)$ & $503(32.7)$ & $1132 / 3134(36.1)$ & $0(0.0)$ & $\begin{array}{c}3000 / 10354 \\
(29.0)\end{array}$ \\
\hline $\begin{array}{l}\text { Therapy with only one Biologic Drug + } \\
\text { MTX }\end{array}$ & $2378(42.7)$ & $862(56.1)$ & $1545 / 3134(49.2)$ & $27(24.1)$ & $\begin{array}{c}4812 / 10354 \\
(46.5)\end{array}$ \\
\hline $\begin{array}{l}\text { Therapy with more than one Biologic }+ \\
\text { MTX }\end{array}$ & $872(15.6)$ & $141(9.2)$ & $340 / 3134(10.8)$ & $78(69.6)$ & $\begin{array}{c}1431 / 10354 \\
(13.8)\end{array}$ \\
\hline Nr. patients with ESI or $\mathrm{AE}$ & $1070(19.2)$ & $1093(71.1)$ & 1163(37.1) & $27(24.1)$ & $3353(32.4)$ \\
\hline Nr. patients with ESI & $496(8.9)$ & $230(15.0)$ & $249(7.9)$ & $5(4.5)$ & $980(9.5)$ \\
\hline Nr. patients with $\mathrm{AE}$ & $729(13.1)$ & $1075(69.9)$ & $1069(34.1)$ & $24(21.4)$ & $2897(28.0)$ \\
\hline
\end{tabular}

\section{Authors' details}

${ }^{1}$ UMC Utrecht, Utrecht, Netherlands. ${ }^{2}$ Istituto Giannina Gaslini, Genoa, Italy.

${ }^{3}$ Zentrum für Allgemeine Paediatrie und Neonatologie - Asklepios Klinik Sankt Augustin, Sankt Augustin, Germany. ${ }^{4}$ Arthritis Research UK Centre for Epidemiology, University of Manchester, Manchester, UK. ${ }^{5}$ St. Josef-Stif Sendenhorst, Sendenhorst, Germany. ${ }^{6}$ Hamburger Zentrum für Kinder- und Jugendrheumatologie, Hamburg, Germany. ${ }^{7}$ Helios Kliniken Berlin, Berlin. ${ }^{8}$ Olga Hospital, Stuttgart, Germany. ${ }^{9}$ Klinikum Bremen-Mitte, Bremen, Germany.

Published: 17 September 2014

doi:10.1186/1546-0096-12-S1-P7

Cite this article as: Swart et al:: Pharmacovigilance in juvenile idiopathic arthritis patients (Pharmachild) treated with biologic agents and/or methotrexate. Consolidated baseline characteristics from Pharmachild and other national registries. Pediatric Rheumatology 2014 12(Suppl 1):P7.

\section{Submit your next manuscript to BioMed Central} and take full advantage of:

- Convenient online submission

- Thorough peer review

- No space constraints or color figure charges

- Immediate publication on acceptance

- Inclusion in PubMed, CAS, Scopus and Google Scholar

- Research which is freely available for redistribution

Submit your manuscript at www biomedcentral.com/submit
Ciomed Central 